IRINA STARODUBROVSKAYA

\title{
Islamic Reformation: The Value of a Heuristic Approach
}

Translation by Marcus C. Levitt

DOI: $10.22394 / 2311-3448-2018-5-1-4-34$

Irina Starodubrovskaya - Ye.T. Gaidar Institute for Economic Policy; Russian Presidential Academy of National Economy and Public Administration (Moscow, Russia). irinas@iep.ru

This article explores the analytical value of "Islamic Reformation" as a concept for analyzing the current situation in the Islamic world. It compares different approaches to religious reformation, including those applied to the Protestant Reformation. Delineation of the characteristics of reformation makes it possible to demonstrate that current tendencies in the Islamic world are quite similar to those that occurred during the Reformation and that some groups of Islamic fundamentalists can be considered as the driving force behind this new reformation. This means that it is incorrect to assess all their values and influence as archaic, reactionary, or fascist. The Islamic fundamentalist worldview contains both modernizing and anti-modernizing features, and some elements of their influence on society are of a modernizing nature.

Keywords: reformation, Islamic fundamentalism, Protestant ethic, modernization, individualism, generational conflict.

Originally published in Russian as: Starodubrovskaya, Irina (2017) "Islamskaya reformatsiya: ehvristicheskaya tsennost' podkhoda,” Gosudarstvo, religiia, tserkov'v Rossii i za rubezhom 35 (3): 11-50.

The article is based on materials from the 2016 research project "The Transformation of Values in Conditions of Modernization in the North Caucasus," at the Ye. T. Gaidar Institute of Economic Policy. 


\section{Islamic Reformation - Legitimation of the Concept}

$\mathrm{E}$

VENTS in the contemporary world are in many respects determined by the dramatic changes that are characteristic of Islamic society: religious revival, an intensification of conflict, and a sharp increase in the political role of aggressive fundamentalist views that call for a return to origins and restoration of the Islamic caliphate. However, despite the enormous significance of these processes, they have not been considered from a systematic theoretical perspective, and existing assessments of them vary greatly.

Thus if one looks at those Islamic phenomena that experts call fundamentalist or neo-fundamentalist, Salafi or Wahhabi, one finds a variety of interpretations. One widespread position, deriving from Bernard Lewis (Liuis 2003), is characterized by a sharp opposition between the Western modernizing and the fundamentalist models of development. This logic sees fundamentalism as ideological traditionalism, as a desire to return to the past, to the Middle Ages. Another interpretation recognizes the modern character of fundamentalist trends, but links them to the "dark side of modernity": "Militant Islam is best understood not as a religion but as a political ideology. Indeed, it is the successor of both fascism and Marxism-Leninism in its nature (radical utopianism), its means (totalitarianism), and its goals (world conquest)" (Pipes 2008). Finally, among intellectuals there is also the view that considers Islamic fundamentalism as a modernizing ideology without reservation:

From this perspective fundamentalist Islam and related nationalisms represent an ideology that seems much closer to that of the French Revolution than for those who limit themselves to the general stereotype that opposes Western Enlightenment to religion in general and to the Islamic East in particular. (Kalkhun 2006, 225-26)

A number of well-known researchers of Islamic issues in the North Caucasus, in particular, in Dagestan, hold a similar position: "Salafism may be regarded as an ideological shell for the process of social modernization and for the separation of the individual from the clan ties that still cement Dagestani society" (Makarov 2000, 27).

Such unequivocal statements suggest that this phenomenon is something profoundly heterogeneous, contradictory, and that it influences events in an unpredictable (non-linear) way. They recall a period of Western history that manifested very similar tendencies - 
a surge of active religiosity, a desire to return to sacred texts, the spread of religious knowledge, and the desire to transform not only faith, but also the life of every person in accordance with religious dogma. I am referring to the period of the Reformation, the emergence of Protestant views in Europe. Can the analogy with the European Reformation help us to understand the processes taking place in the modern Islamic world? Admittedly, using a framework connected to the Reformation to analyze Islam is far from new, and its use has been interpreted variously. ${ }^{1}$ Some scholars consider it unacceptable "Eurocentrism":

This is simply metaphorization, using a concept for Islam that was developed in a different (non-Islamic) culture and environment and intended for conceptual exploration of another religion (Christianity). It is as if when discussing a camel, metaphorically called "a ship of the desert," one would begin to argue about shipbuilding instead of investigating the camel itself. (Ignatenko 2005, 30)

By making use of such a vivid metaphor Alexander Ignatenko is trying to explain the impossibility of the notion of "Islamic reformation" by citing the fact that the Islamic community (Ummah) does not have one single, officially recognized doctrine, such as Catholicism in the Western Christian world, but is divided into many sects. Therefore, it is wrong to "look at the history of Islam from the standpoint of Christianocentrism" and to assume that "in medieval Islam, there was either 'orthodoxy' or 'heresy," because "in fact Muslims have different, divergent opinions on various questions" (Ignatenko 2005, 35 and 26). If we see the Reformation as a purely religious phenomenon, then such a position has some basis. However, from the theological point of view the Reformation, in a general sense, was a typical religious schism in which the official religious tradition of the Catholic Church was opposed by other interpretations, in particular, those based on St. Augustine. ${ }^{2}$ In this case, the special term "reformation" is not at all

1. For greater clarity, in the following text I will write "Reformation" with a capital letter if it refers to a specific historical period, e.g., the Protestant Reformation, and in lower case when the term refers to a broader phenomenon that may be applied to various historical periods. In quoted material, the spelling of the term follows the quoted source.

2. The basic ideas on which the leaders of the Reformation relied - justification by faith; the original sinfulness of each person, connected with the fall of Adam; the predetermination of who is saved and who is not, irrespective of the personal qualities and actions of an individual, and established before the beginning of time; the true church of the righteous - were all formulated in the fifth century by St. Augustine. "The old 
necessary. However, as is widely recognized, the Reformation was not only confined to the religious aspect:

While the old framework tended to hive off the Reformation and portray it in strictly religious terms by tracing its outbreak to the corruption of the Catholic Church and its diffusion to the mass appeal of Luther's teachings, recent scholarship has attempted to set the Reformation within a wider context, emphasizing the importance of social factors in its reception and of political factors in its propagation. (Gorski 2003, 17)

If we analyze reformation as a social and political phenomenon, there are clearly additional possibilities for meaningful analogies. In such a context, the notion of the cyclical nature of reformation in Islam has had some traction. In this view, Islam is characterized by periodic "cleansings," "returns to the basics," which, however, have had a conservative character and have not spawned an ideology pushing for active social change.

Therefore, the historical role of the Christian Reformation and the Islamic reform movements of the Wahhabi type has been completely different. The Christian Reformation opened the way for the free development of society, creativity in all spheres of life, and the constant emergence of the new. Reformation movements in the Muslim world, on the contrary, return society to the perpetual model of shariata, "to the way things were.” (Furman 2011, 217)

Ernest Gellner, who distinguished between a high, in essence fundamentalist, culture in Islam, and a grassroots, mass culture, has made a major modification to this kind of model. Gellner recognizes the cyclical nature of Islamic reformation only for certain stages of the development of Islamic societies:

The functioning of Islam in a traditional society can be described as a continuing or constantly renewed Reformation, in each cycle of which the Puritan impulse of religious revival reinforces the intensification of the directly opposite social trends and demands. Thus, in the past reforms have always been cyclical. (Gellner 2003, 30-31)

Church was immensely strong, and that strength could only have been overcome by the explosive power of an idea. The idea proved to be a new statement of Augustine's ideas on salvation" (MacCulloch 2003, 110). In one of the letters Luther wrote to a friend he referred to "my theology, that is, St. Augustine's theology" (see Chedvig 2011, 45). 
However, Gellner believes that in modern society the rules of the game have changed. These changes - the destruction of the autonomy of self-managed rural communities, urbanization, and the strengthening of the centralized state - have increased the attractiveness of the fundamentalist version of Islam for average Muslims, who have more and more begun to live in cities. It is precisely in a tradition of "high," fundamentalist Islam and its success among the broad masses of the population that Gellner sees a "pass to the future" for Muslim communities.

Its main features are the recognition of the normative nature of the sacred texts, puritanism, individualism, regularity, a relatively small number of magical elements, intolerance of disorganized mystical and ritual practice of the common-folk, and all this, of course, belongs to the number of qualities that are able to alleviate the labors and hardships on the long road to a modern, disciplined industrial society. High Islam was as if especially designed to achieve this goal. (Gellner 2003, 34)

Olivier Roy's position on the issue of Islamic reformation is rather contradictory. On the one hand, he cites many parallels between current trends in Islam and the religious schism of the Reformation, seeing direct analogies with what Max Weber and Michael Walzer wrote about this period (Veber 2001; Walzer 1965). On the other hand, he treats the peculiarities of contemporary Islam according to the logic of "New Age" religiosity.

What we understand by "new forms of religiosity" does not imply, without excluding it, the "reformation" of Islam in the sense of the Protestant Reformation of the sixteenth century, because "re-Islamization" does not entail a reexamination of basic religious dogmas. (Roy 2004, 5)

Roy believes that the same preconditions that lead to fundamentalism may lead to Islamic reformation, and these are: a critical approach to dogma, the desire for ijtihad, and the development of theological thought. He recognizes the existence of "many Muslim thinkers who advocate the rehabilitation of such a critical approach, using the tools of modern intellectual inquiry such as history and linguistics," but notes that "such thinkers do not meet the expectations of young 'born again' Muslims" (Roy 2004, 182). That is, he connects reformation not so much with fundamentalist, Puritanical views, as with more liberal approaches.

The idea of linking reformation with liberal trends in Islamic thought that seek to reconcile Islam with modern ideas about a well- 
ordered society is also quite common. The publication of the book by Abdullahi Ahmed An-Naim, a Sudanese scholar-theologian, Toward an Islamic Reformation: Civil Liberties, Human Rights, and International Law, contributed to the fact that reformation became associated with such ideas. An-Naim sees the task of his work as supporting a revolutionary approach to Islamic legal reform that would promote the acceptance of Sharia law in forms that would allow Muslims to enjoy the benefits of social progress, but at the same time not go beyond Islamic law. The author proposes to build on the approach worked out by his teacher, Mahmud Muhamed Taha, who distinguished "two levels or two stages of the sacred message of Islam, one of which refers to the early Meccan period and the other to the late, Median one" (AnNaim 1999, 65). The Meccan ayahs are based on universal values and recognized the equality of men and women and the right to complete freedom of choice in questions of religion and faith, while the Median ayahs permit the use of force in spreading Islam and in the struggle against unbelievers. Following his teacher, An-Naim claims that the Meccan ayahs are of more fundamental significance, were directed toward the future, and should be used in modern Sharia law.

Despite all of the diversity of views regarding Islamic reformation, they are united by the fact that in practically no case has the question been raised about what reformation is, apart from its specific historical circumstances, that is, reformation as a phenomenon that may be viewed in different historical contexts. Actually, going beyond surface analogies and conducting meaningful analysis are possible only if the content of this process can be separated from its concrete historical "shell." Moreover, most of those who try to spread the term "reformation" beyond the limits of the specific phenomenon within the framework of the Christian world usually manifest a rather superficial knowledge either of that period or of Islam and the processes taking place within it, which inevitably leads to distortions. Therefore, before speaking further about Islamic reformation, let us try to understand how it is possible to define reformation as a social phenomenon without limiting it to a specific historical period.

\section{The Social Content of Reformation}

Religious reformation may be characterized as the movement of large masses of people who, under the influence of newly interpreted religious imperatives, reject their heretofore habitual way of life and implement new patterns of social behavior in accordance with their new 
religious ideals. Within the framework of the Christian Reformation, a number of factors contributed to the emergence of such a mass movement.

First, the Reformation brought the Bible closer to the average believer. "Luther supported Erasmus's appeal that a farmer should read Scripture in between breaks in work or a weaver to the sound of his loom" (Chedvig 2011, 56). This directly resulted from its ideology, the key ideas of which were: the impossibility of the church mediating between God and people, its lack of any influence on a person's salvation, and the key role of the Bible in all questions of dogma and being. Based on this, "Protestantism raised reading and contemplating the Bible to the level of compulsory religious precept and created a cult in which the central place was a pastor's explanation of the Bible" (Furman 2011a, 104). This fundamentally differentiated the Reformation from orthodox Catholicism, for which parishioners were not expected to study the sacred texts themselves, independently. Indeed it was forbidden to keep sacred books at home; the Inquisition could prosecute the believer for doing so. ${ }^{3}$ The liturgy was conducted in Latin and the congregation perceived its performance more as a magical ritual than as a conscious action.

In contrast, the Reformation made sacred texts and rituals maximally accessible to lay people. The Bible was translated into believers' native tongues. "The fathers of the Reformation" themselves made a significant contribution to this process - Luther translated the Bible into German, Calvin into French. The liturgy was also conducted in national languages and preaching took on an incomparably more important role in the service. In order for people to read the sacred books themselves, reformers supported the improvement of literacy as well as preparation of qualified clerics able to explain the basic ideas of the scriptures. The invention of printing also made it easier to carry out these tasks, and the Bible was published in print runs that were huge for the time.

Second, as a result of independent reading, ordinary believers began to interpret the holy scriptures independently for the first time. Luther's opponents complained "that simple people like the Bible, so that shoemakers and elderly women read it and argue about its texts" (Chedvig 2011, 74). There were obvious risks in this. "Everywhere the Bible in the living tongue becomes the source of heresy" (Fur-

3. In England, a person's possession of the Bible translated into English (the so-called Wycliffe Bible) could result in being burned at the stake as a heretic. 
man 2011a, 55). ${ }^{4}$ The possibility of interpretation immediately gave rise to disagreements, related both to the individual characteristics of believers and to their social status, needs, and interests. The Reformation split into many different groups and currents that collided and clashed with one another. These groups were indeed very different: some perceived religion as purely rational; others hoped for revelation from above; some wanted to hide themselves and flee the world; others, on the contrary, sought to change the world in accordance with their ideals; some sought peaceful transformation in cooperation with the authorities; and some provoked and supported disobedience and rebellion.

Usually such fragmented reformatory thinking suggests its weakness.

The authority of the papacy was shaken, and the breach in Catholicism was quite significant. But there was a schism in the camp of the attackers - the numerous sects that grew up as a result of the religious revolution clashed with one another, diluted their power, and suffered the loss of trust at a time when, having recovered from its first defeats, the Catholic Church began to gather its forces for a new, fiercer struggle. (Prozorovskaia 1995, 171)

However, in view of what has been said earlier, it seems that this was not a defect, but an immanent feature of the Reformation. If the Reformation had been monolithic, it would simply have led to replacing one system of dogma with another similar system, that is, we would have observed a church schism. However, the Reformation played a different role. The reading and interpretation of sacred texts by ordinary individuals turned religion from a set of dogmas that were divorced from people and not subject to question into a way of understanding the world in religious categories. At the same time, thanks to its diversity, the Reformation was able in one way or another to respond to the interests and demands of a wide range of social groups poor peasants and noble knights, rich aristocrats and poor priests, protesting intellectuals and powerful princes - and thus created a broad social base for itself.

4. Luther himself, who originally proclaimed the principle of religious freedom, was later horrified at its consequences. These words were attributed to him at the end of his life: "I would leave the great majority of incorrigible sinners under the yoke of the pope. Indeed the Gospel is of no use to them and only leads to the abuse of freedom" (see Porozovskaia 1955, 161). 
Third, the Reformation reflected the massive need for a new understanding and the creation of a new attitude toward reality. "Luther revealed to the world what it wanted to hear from him" (Chedvig 2011, 50). The active processes of social change during early modernization generated this need. What people previously perceived as stable and unshakable now changed before their eyes. The boundaries of the inhabited world quickly expanded as a result of geographical discoveries, creating fundamentally new perspectives and risks: from opportunities for mass migration to the American continent to inflationary processes generated by the flow of precious metals from newly discovered lands into Europe. Familiar social stratifications broke apart: in a number of areas the old aristocracy lost its position, which was now assumed by the state or by previously unknown, newly wealthy families. Formerly despised occupations suddenly turned out to be the most promising. Intensive processes of urbanization overcame the previous isolation of urban and rural communities and thereby forced them to reconsider their role and place. Periodic epidemics created an additional feeling of uncertainty and instability, as the most terrible of them, the plague, regularly devastated huge territories. All of this disorientated people, forcing them out of the usual rut, creating a feeling of chaos, and it forced them to look for at least some point of support. "The world around was changing, creating confusion and disorientation" (Armstrong 2013, 90).

In the changed conditions, someone had to provide an answer to the new problems, and the reformers did offer their own interpretations and solutions. "Calvinist theology already mirrored the new social reality and suggested a general explanation: nothing but disorder could possibly follow from the activity of fallen man, restless, lustful and disobedient" (Walzer 1965, 204). Hence followed the conclusion that "only God's command, only the perpetual struggle of his saints, imposed some minimal order on earth" (Walzer 1965, 161). Thus, the Reformation framed a demand for the large-scale transformation of generally accepted practices in response to social change and to the demands that religious dogma posed for the true believer. Following the reformation of the church came "the reformation of life." "Monarchs, priests, nuns, merchants, farmers, labourers were seized by ideas which tore through their experiences and memories and made them behave in new ways, sometimes admirable, sometimes monstrous" (MacCulloch 2003, 110). It was believed that if one did not seek to comply with the prescriptions of the Supreme Being, it was a sign that one was not elected to salvation and did not take part in the "true church." 
For Calvin and his followers, the justification of the individual believer was a gradual process in which the old Adam died, and a new Adam was reborn. This process of conversion or rebirth was marked by growing conformity of the believer's actions to biblical law, that is, by increasing self-discipline. (Gorski 2003, 124)

This process was fundamentally different from the external control of behavior on the part of the authorities. "Social discipline took on new meaning when enforced through conscience, instead of being imposed on consciences that were free, or modified by the intervention of nature, blood, or patriarchy with all their affective and emotional connotations" (Walzer 1965, 57). But the "saints," feeling themselves to be the advance guard of the divine army that was called by the Almighty to protect the faith, demanded universal adherence to the norms arising from religious obligations. Self-discipline of the righteous was complemented by universal discipline enforced by the secular authorities. "If the ungodly could not be saved, . . . then they could at least be compelled to obey God's laws" (Gorski 2003, 31).

At the same time, the "laws of the Most High" were interpreted to approximate what is contained in the scriptures as much as possible. If Luther stressed the unconditional fulfillment of secular laws, Calvin "looked more closely at the moral principles contained in the Bible, and, additionally, 'sought out' everything in the Bible which can be interpreted as specific rule of conduct. Calvin's followers attempted to present all Old Testament moral legislation as mandatory and sacred law" (Furman 2011a, 89). Thus in Calvinist Geneva the death penalty was imposed for a variety of transgressions "completely in the spirit of the Old Testament" (Furman, 2011a, 89).

And here emerges the basic paradox of the Reformation. The prerequisites for social progress, the development of the free market, the emancipation of the human person, the triumph of liberalism - all

5. In Calvin's Geneva a person could be severely punished for the slightest fault or deviation from the directives that, according to the Calvinists, followed from divine law. "Rich and poor, men and women were required to appear before the terrible tribunal for the merest, accidentally spoken word; for an inappropriate smile during a sermon, for overly fancy clothing, for curled hair, they received angry reprimands, were publicly pilloried, and were subjected to ecclesiastical excommunication, fines, imprisonment [. . .]. A cabby who cursed his stubborn horse in the heat of the moment was imprisoned" (Porozovskaia 1995, 231). Even more severe punishments were widely imposed, in particular, the death penalty. Over five years in Geneva, fifty-eight death sentences and seventy-six decrees of exile were approved (Porozovskaia 1995, 230). The situation reached a point of absurdity. "In 1547, a special decree confirmed a decree of 1535 against the wearing of trousers with slits as something disseminating disorder" (Chedvig 2011, 87). 
were laid by religious fanatics seeking to return to the past, completely subordinating human life to religious prescriptions, forcibly imposing their views, and insisting on the hopeless depravity of human nature and the impossibility of achieving salvation by one's own efforts.

At the source of bourgeois ideological development are not humanist liberals but the frenzied monk Luther who was fighting against carnal temptations and Calvin, who burned "witches" and "heretics" at the stake without a twinge of conscience. The paradox of the liberating and progressive influence of ideology that pulled backward, asserting human frailty, is a real paradox. (Furman 2011a, 42-43)

To explain this paradox is one of the main challenges facing any researcher of the Reformation. It seems important to note the following features of this social process.

On the one hand, the Reformation seriously undermined those traditional relations inherited from the past within whose framework life had previously been organized. That is, if I may put it this way, it cleared the space for the formation of a new reality. Indeed, the Reformation opposed the fundamental principle of traditional patriarchal relations in which all public structures - the community, the state develop out of the family and clan and reproduce (at least on the ideological level) their characteristic social ties.

Thus the Reformation opposed hierarchy as the fundamental principle structuring all social relations. The hierarchy of the church, the hierarchy of feudal status, had been traditionally interpreted as a reflection of the natural harmony of the universe. In the view of the Protestants the structure of the universe looks completely different - no natural hierarchy exists, and all phenomena and forms are the direct result of divine will. "A stone will not fall from a mountain without God's will, just as the sun rises only by the will of God" (Furman 2011a, 64). Subordination to divine will is man's unequivocal duty. The obligation to submit to the authorities was also preached by many Protestant movements, but gradually the radical supporters of this trend came to the conclusion that submission is necessary only to the extent that the authorities do not violate God's will. In addition, the Reformation sought to destroy those natural, primordial ties that structured traditional society in favor of the primacy of ideological unity. Family, friends, ancestral land - all these the true believer had to be ready to abandon. Taking their place was the community of like-minded people, bound by a common ideology and a common desire to fight for the tri- 
umph of God's word. The chosen "would not be blinded with those vain shadows of fathers, times and customs, but would measure the truth of religion by the squire of the Word" (John Stockwood, "A Sermon Preached at Paul's Cross," London, 1578, cited in Walzer, 1965, 187).

On the other hand, the Reformation helped form a new system of modernizing values, whose influence was manifested both directly and indirectly in several ways:

1. Certain of its aspects directly contributed to the advancement of modern values;

2. A phenomenon arose that Weber described: "in significant measure, the cultural influences of the Reformation [. . . ] were unforeseen and even undesirable consequences of the activities of the reformers themselves, often very far from what they thought was happening or even directly opposed to their true intentions." (Weber 2011, 69)

3. By itself, the religious pluralism formed under the influence of the Reformation dictated the norms that one had to follow sooner or later.

The importance of education and conscientious work were the most obvious modernizing elements of Reformation ideology. Thus Luther called for the creation of public schools for all classes of society as well as public libraries and thought that this was one of the most important duties of the Christian authorities. Many Calvinists also sought to promote reform programs related to public education. As for the new relationship to work, within the framework of the Reformation this was determined by the fact that the reformers sacralized all human activity, considering it a ministry, a vocation. Protestants denied the superiority of ecclesiastical ascetic duty over worldly responsibilities. On the contrary, "the performance of duty within the framework of one's worldly profession is regarded as the highest task of the moral life of man" (Weber 2011, 49). Success in professional work was considered a confirmation of the believer's having been chosen for salvation.

At the same time, in the Reformation one can also find embryos of those features that are characteristic of the "dark side of modernity" repression, terror, the subordination of the individual to the depersonalized power of the state, and society's strict regulation of the life of its members. Church and police control over the life of believers in the form that it was carried out under Calvinist state church domination, not only, as Weber believed, reduced and even prevented the liberation of the individual, but also left a visible imprint on the system of relations in modern society. 
The question of the unforeseen consequences of religious reform requires special analysis. To begin with, the Reformation's idea of universal sinfulness affirmed the universal equality of people in a negative way. "Since everyone's nature is equally damaged, everyone is equal in their sinfulness to one another" (Furman 2011a, 67). This was manifested not only in ideology, but also in everyday life. The wife of one of the leaders of the aristocratic Huguenots described with indignation how she was not admitted to communion because of her hairdo, and she observed in a rage how her servants had been allowed to take the sacrament (Walzer 1965, 50).

A more complex question is whether the Reformation really contributed to the advancement of individualism. One cannot disagree with the fact that "discipline and not liberty lies at the heart of Puritanism" (Furman 2011a, 149). Nevertheless, the Reformation evidently strengthened individualism in several ways. In the first place, the rejection of traditional boundaries and hierarchies was itself an act of emancipation. "The formation of ascetic communities and sects with their radical rejection of patriarchal fetters and their interpretation of the commandments to obey God rather than people was one of the most important prerequisites of modern 'individualism"' (Weber 2011, 174).

Secondly, within the framework of the Reformation, salvation is an individual act, not mediated by any intermediate instances, which obviously strengthens the role of the individual as a subject, determining his or her own life circumstances (if not to achieve salvation by one's own forces, at least in order to prove to oneself that one is chosen). Thirdly, the possibility of independent reading and interpretation of the Bible sharply expanded the role of individual judgment in understanding the world around us; "the unprecedented exaltation of Scripture leads to the liberation of the individual from the domination of the church and church dogma.[...] There is no authority in determining its meaning so that human reason turns out to be absolutely free" (Furman 2011a, 70, 72). Fourth, the very act of self-selection of one's own religious worldview in an era of schism and anarchy is a deeply individualistic act.

A fairly common notion is that the Calvinist system of community taught believers the mechanisms of citizenship, democracy and self-rule. The assertion of a new understanding of citizenship was directly related to the rejection of previous ideas about people's political passivity.

The activity of the Calvinist saints, however, required a recognition that all subjects were knowledgeable and active citizens rather than naive 
political children, that government was not a household, the state not an extended family, and the king not a loving father. (Walzer 1965, 14)

At the same time, the demand to submit to religious law, even in small things, promoted the value of abiding by the law as a universal good.

The question of the consequences of the Reformation in the family sphere and gender relations is interesting. "Puritan writers insisted upon the inferiority of the female, but nevertheless recognized in her the potential saint" (Walzer 1965, 193). Marriage between two saints was regarded as a spiritual union. Conflicting notions of the role of women were reflected in the concept of the family as a whole. The Puritan model of the family does not lend itself to an unequivocal assessment in terms of modernization; it departs from the traditional patriarchal ideal but at the same time does not correspond to modern ideas about gender roles and the rights of family members. The family was regarded as a "small church" in which the father had unconditional power and the children were reduced to the position of servants. Rigid methods of upbringing designed to prevent the consequences of original sin were imposed, even among toddlers. Natural feelings, love and tenderness, were suppressed in every possible way. Nevertheless the family increasingly came to be seen as a voluntary union of two individuals united by civil contract. The requirements for divorce, which was extremely difficult in Catholic countries, were eased.

Finally, religious pluralism significantly influenced the situation in the sphere of religious tolerance. The original Lutheran idea about freedom of conscience very quickly came to naught. In the struggle between Catholics and Protestants in Germany, the following principle was worked out: "those in power decide the faith" - subjects must share the faith of their sovereign. It was believed that without a unified state religion the state could not exist. The struggle against heretics was no less cruel in Protestantism than in Catholicism; in both heretics were burning. However, the principle of a unified state religion was not implemented in all countries even where there were numerous conflicts, religious wars and clashes. It was necessary to understand what to do in such situations. The idea that peace with two religions is better than war that does not solve anything became increasingly popular. The Edict of Nantes (1598) in France was the first document to establish the principle of religious tolerance at the state level, and even though it was abolished under Louis XIV it played a major role in affirming the principle of freedom of conscience.

The definitive step toward religious freedom was made on the American continent. That country, in whose creation religion played a key 
role, became the first secular republic. The Bill of Rights of 1789 included this formulation: "Congress shall make no law respecting an establishment of religion, or prohibiting the free exercise thereof" (cited in Armstrong 2013, 112). In this case it was also largely a pragmatic step - the founding fathers understood that "if the federal government gave the status of state religion to one of the Protestant denominations, the constitution would not have been approved" (Armstrong 2013, 113).

However, all these diverse and in many respects positive consequences of the Reformation from the modern point of view only made themselves felt after a considerable period of time. Many contemporaries saw something quite different - fanaticism, mass violence, chaos, outrages upon sacred objects, and a barbarous attitude to works of art in the name of "iconoclasm." Thomas Hobbes wrote that perhaps it would be better to destroy all Protestant preachers before they began to bring their ideas to the masses and to avoid the horrors and losses of civil war in England (Walzer 1965, 114). It was only at a much later time that the idealized image of the Reformation as a process aiding the modernization of society appeared. It is this kind of image that scholars who write about the Islamic Reformation often envisage.

\section{Islamic Reformation: What Can a Conceptual Frame- work Provide?}

The proposed consideration of contemporary fundamentalist Islamic trends through the prism of the Reformation is not made in order to draw a beautiful analogy. This conceptual framework can help find answers to the following critical questions concerning contemporary analysis of the Islamic world:

1. What is the reason for the wide dissemination of and call for Islamic fundamentalism?

2. What functional roles does fundamentalism play?

3. What are the consequences of this ideology? Can Islamic fundamentalism contribute to the modernization of the societies in which it spreads, as happened with the Reformation in Europe?

Regarding the first question, we should remember that the demand for a religious reformation in Europe arose in an era of global change; in the new conditions, people were not satisfied with the usual answers

6. "A crowd, inflamed by iconoclastic sermons, broke into a church, stopped the Catholic service, and desecrated their holy things" (Porozovskaia 1995, 120). "Protestant actions were identified with the looting of churches, destruction, irreverence, religious anarchy" (Chedvig 2011, 133). 
to the basic questions of being. "Old values inherited from the past came into conflict with the material and intellectual aspirations of the present" (Chedvig 2011, 15). The Reformation gave people an opportunity to seek answers independently and suggested new directions for searching.

The Islamic world is also undergoing profound transformation today. Accelerated modernization carried out by many secular regimes in Islamic countries has seriously shaken the traditional system of relations, caused sharp social changes and intensified urbanization. Globalization and active migration have also significantly changed the living conditions of large masses of people. In these conditions, can the ideology of Islamic fundamentalism satisfy the demands that Muslims have as a response to the demise of their customary institutions?

Many researchers from various countries have tried to answer this question. ${ }^{7}$ I will try to do so on the basis of field work I conducted in the North Caucasus. ${ }^{8}$ At first glance, it may seem that this region, which is on the periphery of the Islamic world, cannot serve as an adequate object of analysis. However, I would like to emphasize once again that the object of study in this case is not the religious, but the social aspect of reformation, and from this point of view the situation in the North Caucasus is quite indicative. The population is experiencing the same processes and the same problems as in many other Muslim-populated areas: the legacy of traditional society and its decay; urbanization and globalization; the consequences of the collapse of the official (Soviet) ideology; and military conflicts.

If we consider as an example the most Islamized of the Northern Caucasian republics - Dagestan - then it becomes obvious that in the 1990 s this territory experienced a radical breakdown of the previous developmental model. This breakdown resulted from:

- the collapse of the socialist economic model, the consequences of which were reinforced as a result of the dissolution of economic ties during the Chechen war;

7. In this respect, Olivier Roy's Globalized Islam: The Search for a New Ummah (2007) is one of the most interesting works.

8. This was a study I conducted over five years in the republics of the North Caucasus with predominantly Islamic populations. Its subject was the prerequisites, the course and consequences of Islamic radicalization, as well as the nature of intra-Islamic conflicts. The study was conducted using qualitative sociological methods in the main cities and approximately twenty-five villages of Dagestan, Chechnya, Ingushetia, KabardinoBalkaria and Karachaevo-Circassia, and included about a hundred individual and group interviews that were held with Islamic fundamentalists themselves. Quotes in the text are taken from these interviews as well as from statements by Islamic fundamentalists on social networks. 
- active migration processes: the outmigration of the educated population of Dagestan's cities to other regions; the mass inmigration of mountain people to the plains, in the first place, again to cities;

- the involvement of rural communities in market relations that have undercut their isolation;

- globalization in both the "Western" and "Islamic" senses;

- the war in Chechnya, a neighboring republic with Dagestan.

To one degree or another, similar processes are typical for almost all of the North Caucasian republics.

Young people who entered life during this period faced numerous problems and difficulties, and these difficulties were not just economic. The destruction of norms and rules of both urban and rural culture caused by mass migrations ${ }^{9}$ left a normative vacuum that scholars following Emile Durkheim call anomie (the lack of norms, lawlessness). In the absence of generally accepted norms the cost of interaction among people proved to be extremely high. When "the rules of the game" are suspended the "right of the strong" plays the dominant role. Moreover, in such a situation, young people as a group cannot rely on the experience of forebears and use their life models in order to succeed; this experience had been formed in other circumstances and lost relevance in conditions of social breakdown. Generational hierarchies began to play a negative rather than a positive role - they prevented active adaptation, inhibiting young people's search for their own values, meanings, patterns of behavior and interactions with the outside world. ${ }^{10}$

What kind of needs did young people have in such an environment? Based on the field studies I conducted, they may be formulated as follows:

1. The need for a strict system of rules and norms that would somehow allow the surrounding normative chaos (anomie) to be restrained.

9. This culture itself was formed as a result of the influence of Soviet power on the North Caucasian peoples' traditional way of life. It is necessary to understand that, first, its impact was not uniform; in some places it essentially transformed existing social relations, while in others it affected them in a purely formal way; and, second, that Soviet modernization itself was conservative, that is, it did not destroy very much, but tended to preserve the rules and restrictions characteristic of traditional culture.

10. Despite the abundance of work on Islamic issues in the North Caucasus, analysis of the social consequences of post-Soviet transformation is poorly represented. A successful example is the work of Enver Kisriev, in particular, Islam i vlast'v Dagestane (2004). 
2. The need for a community of like-minded people that could compensate for the weakening of the role of generational, family hierarchies, and, in conditions where "the right of the strong" predominates, guarantee the security of its members.

3. The need to legitimize intra-generational conflict and to increase room for the independent exploration of values and ideas.

4. The need for an outlet for social protest, to demand an alternative to the lack of order and justice that is observed all around.

Islamic fundamentalism proves to be competitive in the market of ideologies because of the way it satisfies these needs overall. It provides strict normativity and regulation in the life of believers, giving them a point of support in an atmosphere of chaos, and includes them in a community of like-minded people who share the same "rules of the game." It expands the possibilities for independent study of the sacred texts and for choosing one's own teachers. To some extent it legitimizes inter-generational conflict, because "if we take the paternal word and the word of the Most High, the word of the Most High is superior" (male, young, NGO, Dagestan, Makhachkala). And, finally, it acts as an ideology of protest, juxtaposing the existing state of society to an alternative social ideal - the Islamic caliphate, which is capable, in the opinion of its adherents, of ensuring order and justice.

None of the other ideologies on the "market" can satisfy these demands as successfully. Traditional Islam ${ }^{11}$ is hardly able to insure the legitimization of inter-generational conflict (this is the religion of the

11. Not all Islamicists accept the term "traditional Islam," but it is widely used as an antipode to fundamentalist currents that have been dubbed "nontraditional Islam." "The concept of 'traditional Islam' is rather vague and is not easy to define. In different regions, different peoples follow various 'traditional' Islamic trends. For example, part of the population of the North Caucasus belongs to the Hanafit madhhab, part to the Shafi'it, and these madhhabs (Islamic trends or schools of law) have their own approaches to the legal and ritual interpretation of Islam. Sufism, a mystical current in Islam, also has its special character, one that implies unquestioning obedience to a spiritual leader (sheikh); moreover, among the various sheikhs, there may also be inconsistencies. In addition, traditional Islam can be interpreted as 'popular Islam,' a system of beliefs that have come under the influence of non-Islamic customs and traditions, something that is unacceptable to those who have received a proper Islamic education. Some equate traditional Islam with official Islam, represented by a religious governing body on a particular territory, although in different regions they may represent different Islamic groups" (K. Kazenin and I. Starodubrovskaia, "Severnyi Kavkaz: Quo vadis?; Ekspertnyi dolklad,” Polit.ru, http://polit.ru/article/2014/o1/14/caucasus/, accessed August 20, 2017). However, what unites all of these interpretations is the idea that "traditional Islam" represents the "correct" Islamic religion that dominated the corresponding territory prior to the beginning of the Islamic revival and that in modern conditions it was in one way or another supported by state authority. 
fathers) or of social protest (as it usually coincides with official Islam, supported by the state). Nationalism (in the case of the North Caucasus - ethnic mobilization) may well serve as an ideology of protest, but in many cases does not provide particular norms (although some ethnic groups do have their own ethnic codes of behavior) and it does not legitimize intergenerational conflict. Liberalism in general is often seen not as a "remedy," but as a "source of illness" - a source of chaos and injustice.

Putting anomie forward as a reason for the popularity of fundamentalist Islam departs from the widespread opinion that its causes are connected with the sense of inferiority Muslims feel in connection with their loss of world leadership and inability to be competitive in comparison with Western countries. ${ }^{12}$ Without denying the role of such broad phenomena, one should note that they are perceived much more acutely when a person sees their reflection in his or her personal life. Thus, the slogans about the oppression of Muslims around the globe and the need to take revenge for it find a more favorable reception if the audience feels alienation, the denial of social advancement, and discrimination.

Analogies between the spread of Islamic fundamentalism and the Reformation are striking. In Dagestan, for example, traditional, official Islam is Sufism, which assumes complete submission to the authority of the sheikh and does not welcome independent study of the sacred texts. ${ }^{13}$

For us there was only Sufism, we were all brought up in the tradition of Sufism. This means we did not ask unnecessary questions [. . .]. There was complete unanimity. (male, old, public figure, Makhachkala)

In young people, this kind of attitude provokes active resistance:

We read. That is, I read the translation of the Koran, I read the hadi. Yes, at first, as a child, there was blind repetition: the imam spoke, and that's what you did [...] Sufis, they said - do not read translations. The

12. This position is held, for example, by Daniel Pipes, who used to connect the rise of Islamic fundamentalism with the oil boom, but then changed his opinion. "More basically, I no longer try to account for the rise in militant Islam with a single explanation [. . .]. The Muslim world feels something has gone very wrong, but has been frustrated in its attempts to right matters" (Pipes 2008, x). The position presented in the current article is much closer to that of Olivier Roy (2004), who explains the spread of neo-fundamentalism by deculturation, generation gap and social protest.

13. In cases where official Islam is not associated with Sufism, the same problem of unconditional submission to the authority of the imam still arises. "What the efendi does, it means, what everyone [...] must do" (male, old, imam, KChR, village of the plain). 
book [the Koran] is given to people [. . .] Read but do not interpret; if you want, there are interpretations. We should study this, we are not stupid sheep to follow the shepherd. (male, young, student, Makhachkala)

The independent reading of primary sources contributes to the formation of one's own opinion on how the sacred books explain life and what they require from a believer. People understand the limits of independent interpretation of the Koran and the Sunnah differently. A moderate option is reasoned choice based on the positions of various scholars:

When I say that this is incorrect, I did not discover this by myself. I follow some scholars who have investigated this issue and come to this conclusion. It satisfied me, this research, and I accepted this position. (male, middle age, imam, KChR, village on the plain)

We turn to those who know, who have studied [...] And we do not stop at one instance. We ask one of them here [. . .], then we go to the other knowledgeable person who has studied, and we ask him. And then from all of these we do what will be better judging by our region [...] We look at what is allowed and what is clearly forbidden [...] And if all three of them say that it is prohibited, then we put it off. But if one says - you can, and another says - you cannot, and another - you can and you can't, it's just that kind of situation, we take [into consideration] the circumstances that we find ourselves in and do what is best. That is, according to our region, we know better [how it is] in our everyday life. [. . .] [We decide] How it will be better for society, and so that it does not contradict the canons of Sharia. (male, middle age, works in the North, KChR, village in the plains)

However, there is also a more radical approach, recognizing each person's right to independently search for the truth: "Every Muslim should seek the truth. [. . .] The Prophet exists, so let him be my sheikh. And the rest are just ordinary people" (male, young, worker, Dagestan, mountain village). Naturally, the variety of interpretations leads to a serious fragmentation of Islamic thought. To a certain extent one can agree with the widely held opinion that such division is largely due to the inadequate knowledge of Islam among its adherents. This is about the same thing that Luther feared during the peasant war in Germany when the slogans of the Reformation were used to justify the peasants' struggle for their rights. ${ }^{14}$ However, by contrast, this

14. During the peasant war in Germany, the peasants, under the banner of the Gospel, "demanded the abolition of serfdom, the reduction of tithes and other feudal duties, the 
means that people began not simply to follow dogmas, but had the opportunity to understand the world in religious categories, taking into account their own position, interests, and individual character. And this new way of thinking led to various results.

Thus among fundamentalists one may find advocates of very different views: apolitical people who want to fence themselves off from society and live in a narrow circle of like-minded people, strictly observing Islamic norms; supporters of peaceful Islamic proselytizing (preaching, attracting new adherents); advocates of political action and the struggle for the rights of Muslims; finally, supporters of the armed struggle to establish an Islamic caliphate. Globalization, which provides access to worldwide Islamic thought and the diversity of religious trends and groups, gives believers the opportunity to join with the followers of those views that best reflect their life goals and ambitions, whatever they may be.

Here a person no longer seeks, for example, a strong rationale from the point of view of Sharia law; any justification is enough. Not from the scholar whom he always trusted, but from someone who can explain to him that this is allowed. (male, young, NGO, Dagestan, Makhachkala)

The abstract possibility of independent religious choice does not mean that this phenomenon has acquired universal application. In such matters people may still uphold the same familial or rural solidarity and automatically follow their friends or a charismatic leader. $.^{15} \mathrm{Nev}-$ ertheless, such an opportunity fundamentally changes the "religious landscape," individualizes religious beliefs, forces people to reckon

free use of hunting, fishing and forest areas, the return of public pastures, and, at the top of the list, the right to choose their own pastors and evangelical preaching" (Porozovskaia 1995, 127).

15. Scott Atran, studying the way people join in armed jihad, asserts that in most cases this is not chosen as a carefully thought out decision and he cites the results of a study in Saudi Arabia according to which 64 percent of people join the terrorists via friends and 24 percent through their family (Atran 2016, 68, 383). Note that in the era of the Reformation, similar ways of involving people in the Protestant movement were also actively used. Thus, Andrew Phillips observes that in organizing their struggle against the Catholics in France the Huguenots relied on various kinds of mobilization. "Huguenot confessional networks combined the strength and resilience of affective bonds derived from aristocratic kinship and patron-client ties with the command and control capabilities of a rationally organised church bureaucracy to establish a highly effective form of insurgent organisation" (Phillips 2005, 265). On the basis of field research conducted in the North Caucasus, we found that there are many paths for radicalization including those related to group solidarity and those based on individual choice. 
with the presence of "competitors" in the Islamic field and develop strategies for coexistence or struggle with them.

Let us turn to our most important question: what qualities does this ideology foster in its followers? I must say that there is no single answer to this question. In the various trends of Islamic fundamentalism, modernizing and antimodernizing features may manifest themselves in a variety of combinations; modernizing elements may be generated either directly or indirectly as the unforeseen consequences of this or that religious practice.

Let us first try to consider the obvious modernizing consequences of Islamic fundamentalism. A number of researchers who make direct reference to the work of Max Weber argue that Islamic fundamentalism educates a new type of entrepreneur - an advocate of "Protestant ethics." "Conservative in faith and beliefs, but modern in terms of business, a middle class of Islamic puritans with a Weberian work ethic can be seen to be emerging" (Roy 2004, 97). Fieldwork in the North Caucasus does not fully confirm this thesis. Rather, it may be said that the values of conscientious labor and the desire for vertical mobility do exist, however, labor is not seen as a person's duty in the sense of fulfilling a religious requirement as it was during the Protestant Reformation.

At the same time, Islam has had a positive impact on the value of education in this region, which by all accounts is less apparent to researchers in other parts of the Islamic world. Among some Caucasian fundamentalists the following position with respect to secular knowledge is common:
Allah's Messenger said: "Seek knowledge, even if it is in China. Because gaining knowledge is a fard [duty] for every Muslim. And the angels spread their wings under the feet of those seeking knowledge." During the heyday of Islam, many of the exact sciences and medicine also flour- ished. (male, middle age, businessman, Dagestan, Makhachkala)

Here the emphasis on knowledge sounds much stronger than in the context of traditional Islam, in which a number of communities have advocated limits on secular education.

Our generation is like that. When there was traditional Islam under the Communists, our village was religious, and they said - you cannot study at school, let's say. Our own people, the elders, [said this]. It was forbidden to study there in the city, or anywhere, [they said that] according to 
Islam it was forbidden. And we believed them, we followed in their footsteps. Now, when more or less modern times have come, you start to study Islam yourself, and it's completely different. It demands to actually study, [because] knowledge is the most valuable thing. (male, middle age, businessman, Dagestan, village in the foothills)

Moreover, Muslims, especially in Dagestan, are striving not only to postulate the importance of knowledge in theory but also to contribute to its practical acquisition. Some Islamized Makhachkala diasporas support projects that maintain secular school education in their native villages. In Makhachkala itself, as well as in a number of villages, representatives of fundamentalist Islam are opening educational institutions that combine religious education with the serious study of secular subjects using the most advanced educational technologies. As an example we may cite what was said about a children's educational center organized by Muslims in Makhachkala:

What was included in [this program]? There was Arabic, English from the age of three. Arabic according to the Bain Iadayk course, Arabic in Your Hands [...], there was an Egyptian program for kindergartens and we used it. [...] There's also an Oxford course for those from three years old [. . . ] [that went] into it. And it was [for children] from three up to six years old, preschool and preparation for school. (male, middle age, businessman, Dagestan, Makhachkala)

Modernizing influence stems also from modern cultural forms of communication and interaction that are especially important in conditions of anomie, which destroys generally accepted norms and forces villagers to adapt to an unfamiliar urban environment.

Here in the village, if you suddenly do something bad, any elder can give it to you on the noggin. That's normal. And it doesn't matter if he's a relative or not. When you come to the city, no one gives it to you on the noggin anymore. They haven't taught you how to behave, why for example you can't offend a girl. They didn't explain why it was wrong to offend a girl, but simply gave it to you on the noggin. But here you see that nobody is giving you knocks on the head. So it's okay to offend a girl. (male, young, businessman, Dagestan, Makhachkala)

Under these conditions, Islamic fundamentalists perceive themselves as carriers of civilized standards of behavior, as opposed to secular- 
ized young people who are considered to be bearers of a lack of culture and bad habits.

What is modern society today? I will outline a person's values. [. . . ] A person doesn't smoke - that's good. A man doesn't drink - great. A person is engaged in sports - definitely a plus. A person doesn't commit adultery - good. A person works - good. A person does not steal good. But if he prays - ahhh, Wahhabite! (male, middle age, working in the North, KChR, village in the plains)

The most common stories in interviews were about how Muslims are carriers of higher ethical standards and demonstrate this to non-Muslims, thus asserting the superiority of Islam:

This is what happened to me in Moscow, for example. I'm with a friend [. . .], we were standing together at a station waiting for the last suburban train to Kraskovo. [. . .] On the next bench sat two guys. Drunk. They were shouting. I told one, [don't] shout, behave yourself. He shouted something offensive to me. I got up, went toward them. [. . . I I approach them, and they look at me in a way I know they are preparing for something. And I say, guys, people are tired, they are on their way home, and you are not letting them go in peace. . . Be quiet. He is like, struck dumb. They thought there'd be trouble. And they were ready for it, if it was. They were asking for it themselves, with whomever. In general, they said, sorry, blah blah. . . We moved away, back to where we were. . . The whole station was watching. They were thinking, now those bearded guys will go at it, something will happen ... (male, young, NGO, Dagestan, Makhachkala)

It must be admitted that in the era of the Reformation Protestants played a similar role. Their moralizing attracted disoriented and anxious urban migrants, and "the discipline of the congregation taught them the appropriate city style, ensured new standards of order and new habits, separated them from the heterogeneous crowd of the growing city, and as a result gave them self-confidence" (Walzer 1965, 243).

A more difficult question is how to distinguish, with reference to Islamic fundamentalism, an analogue of what Weber considered the activities that gave rise to consequences that the Reformation ideologists did not foresee or desire, and that contributed to modernization. In the first place, such consequences are connected with the fact that fundamentalists (as well as Protestant Reformers) reject tradition and its associated 
social organization and regulation. Sometimes, because of fundamentalists' desire to return to origins, it is said that Islamic fundamentalism supports traditionalism. ${ }^{16}$ This is not true. To understand the paradox that arises here (similar to the paradox of the Reformation), it is necessary to make sense of which past, in fact, the fundamentalists appeal to. Any new religion starts with a charismatic period, a period of the breakdown of stereotypes, of searching and breakthroughs into the unknown, a period of heroism and sacrifice. Then, gradually, a tradition coheres that adapts the demands of religion to the ongoing needs of life, to the interests of those in power, to the routine of everyday existence, and rejects searching and creativity. In Islam, this has manifested itself in the image of "closing the gates of ijtihad,"17 a ban on independent judgment and the creative development of Islam. Therefore, here the past means, on the one hand, the revival of certain archaic rituals and practices, and on the other, the legitimation of spiritual searching. "Knowledge opposes tradition" (male, middle age, worker, Dagestan, mountain village) is the way one interviewee summarized the essence of the intra-Islamic conflict in Dagestan.

What are the consequences of the destruction of tradition that results from the ideology of Islamic fundamentalism? Here are some examples. First, it creates conditions for the formation of individualism. The situation here is very close to that of the classical Reformation. Individualization of the choice of religious views; prioritization of horizontal connections of like-minded people over kinship hierarchies; independent study of sacred texts and the denial of unconditional adherence to religious authorities; subordination to divine directives first and foremost and not to the powers that be; all these factors certainly contribute to the emancipation of the individual and erode the dominance of the collective over a person's individual will. Olivier Roy describes the relationship between neo-fundamentalism and the formation of individualistic values very vividly:

By freeing the believer from the bonds of pristine societies, families, tribes, social status and ethnic solidarities, but also from the bonds of

16. "Periods of crisis [. . . ] significantly increase the interest in historical traditions on the part of people experiencing frustration and depression. Traditionalism, brought to its logical conclusion, is the main prerequisite for various manifestations of such a radical ideological trend as fundamentalism" (Pain 2002, 115). "A general view is that religious fundamentalism is the expression of an increasing rigidity of traditional identities" (Roy 2004, 329).

17. The right of the highest Sharia experts, the mujtahids, to make independent judgment on Islamic laws. 
brotherhoods, religious institutions and traditions, neofundamentalism favours individualism, or more precisely it sacralises the experience of individualization. By appealing to youths over the heads of their parents, by ignoring ulama in favour of a direct approach to the texts, and by encouraging a personal return to the true tenets of Islam, neofundamentalists contribute to the promotion of the individual as opposed to any sort of group or hierarchy. (Roy 2004, 268)

Researchers of Islam in the North Caucasus note analogous processes:

The Salafi demand for the strict, exclusive worship of Allah that is about to absolve the individual from the power of patriarchal clan traditions, providing the highest religious sanction for the tendency characteristic of young people to desire independence and self-determination within the framework of new modern forms of social solidarity. (Makarov 2000, 28)

It is also important that Shariah law does not provide for collective responsibility - the individual is punished for her or his actions.

Secondly, a consequence of the destruction of traditions that result from the ideology of Islamic fundamentalism is the teaching of adherence to law. Not all fundamentalists consider it necessary to follow the legislation of the secular states where they live, but the idea of unconditional observance of divinely dispensed law - the Sharia - regardless of who you are - is one of the cornerstones of the fundamentalist worldview. This differs significantly from traditional legal approaches where the maintenance of hierarchical subordination is built into the normative system of relationships. The difference is exemplified by the reaction of defenders of Adat and Shariah to the practice of honor killing, information about which has been posted on the Internet. The first declare that "it is necessary to obey the men of one's clan, and she [the victim of honor killing] trampled on their moral law. The result is obvious." The second: "This is a real horror. They have no right to stage a lynching."

Education in abiding by the law is also connected to recognizing the inviolability of contractual obligations and of honest behavior toward one's partners. "Look at what a contract is in Sharia law, especially as regards hiring. Any person who violates a contract is a hypocrite. And hypocrites are on the very bottom of hell according to Islamic doctrine" (male, medium age, businessman, Dagestan, Makhachkala).

Thirdly, although the influence of fundamentalist Islam on gender relations is far from unambiguous and, as in the process of the Refor- 
mation, very contradictory, it is still possible to identify certain modernizing tendencies. Islamic fundamentalism does not recognize gender equality but significantly expands women's rights in comparison with the norms of traditional society, at least in some of the North Caucasian republics. In Islam, a woman is a subject of law and may make legal claims on her husband or demand a divorce, and in this context Islam may be perceived as giving women a basis for protest against the tyranny of males. "I now know that I have a right to this. That is, these are God-given rights. [. . . ] Why do you, my husband, oppress me? I can go all the way because God is with me" (male, speaking for his mother, young, businessman, Dagestan, Makhachkala). The change in attitude toward girls in the family, in which they have traditionally been considered "second-rate" in relation to boys, is also important. In many families of Islamic fundamentalists in the North Caucasus there is no such division and girls' upbringing is given much more attention (possibly because the Prophet had a beloved daughter). Change in the conditions of early socialization may significantly affect women's position in adulthood.

Of course, all of these direct or indirect modernizing phenomena are not universal. First, they function in a rather contradictory fashion, especially in those cases where they are manifested not thanks to, but in spite of, implementation of the new doctrines. The end to dictates by elders may lead not to the formation of individualism but to the dictates of the Islamic community and its leaders. Abuse of the requirement for a wife to subordinate herself to her husband may result in her even worse enslavement than before. Secondly, another, alternative value system often exists among fundamentalists that is obviously anti-modernizing: it denies the importance of secular knowledge, actively rejects any interaction with the world outside of the religious community, and combines this with the fostering of social parasitism. Actually, this kind of mosaic of values, combining incompatibles, was also characteristic of the Protestant Reformation.

Effects associated with the enhancement of religious tolerance have not yet been observed. On the contrary, intra-Islamic conflicts are extremely harsh. The widespread notion that "Islam is much broader than any ritual differences [. . .]. The blood of a Muslim is more valuable" (male, young, a public figure, Dagestan, Makhachkala) has not yet matured in the Islamic Ummah. However, within the framework of the Reformation, the idea of religious tolerance also took a very long time to earn acceptance, over the course of many religious conflicts and wars. 


\section{The Direct and Roundabout Path to Modernity}

Analysis of the current situation in Islam in terms of an Islamic reformation that creates the preconditions for modernization leaves open the question: is such a complex path inevitable? Why is it not possible, based on the previous experience of Western countries, to simply introduce modernizing formats that have already been worked out in the course of global social development? It is known that Islamic fundamentalism is opposed not only to tradition, but also to modern models of society that provide for democracy, human rights, and tolerance. As noted earlier, there are thinkers who seek to reconcile Islam with these models. Why can't the reform of Islam occur on their basis, without acute clashes, bloody conflicts and conflicting values?

It must be said that the Protestant Reformation also gives rise to similar questions. At the time of the Reformation, there also existed an alternative ideology that was much closer to contemporary ideas of modernization - Renaissance humanism. The greatness of humanity, its boundless possibilities, the freedom of will, freedom of conscience - all these values were openly proclaimed by the humanists. The Renaissance "symbolized the destruction of old norms and enabled the expression of a brilliant, often fantastic and eccentric individuality that had become possible by the destruction of those norms" (Walzer 1965, 123). But why did humanism not become the basis for social transformation at the time?

There are two likely reasons for this. First, humanism was a very elitist ideology, unable to help ordinary people of the time understand the world they lived in. The ideas of personal self-realization with pleasure as its higher manifestation could attract representatives of the elite but only caused revulsion and condemnation among the masses. Secondly, the humanists, while condemning the vices of society and proposing various reforms, nevertheless did not strive to formulate a comprehensive program for reorganizing the world and they inscribed themselves quite easily into an environment that ideologists of the Reformation radically rejected and resolutely opposed.

In many ways, analogous factors are still at work today. On the one hand, people emerging from traditional systems of social regulation often perceive modern models of society as alien, chaotic, and characterized by total permissiveness and a lack of morality. And this may not have anything to do with religion. Here is the opinion of an undeniably secular man from Dagestan: 
Why do we think that liberal democracy [...] is the single objective path for social development? [. . .] I approach this question from the point of view that [. . . ] the entire process must be subordinate to [. . . ] the phenomenon we call morality. [. . .] Both economic and other processes should [be so subordinated]. [. . . ] If I say to a person: [. . .] It is written on the banners of liberalism to accept human rights, but the collective, the state and so on take second place, and you may not take into account the person standing near you, this will not lead to morality. [. . .] Now I do not believe in anything. This liberalism has brought me to a condition in which I do not believe in anything. I do not believe in the state, and I do not believe in people around me; they pursue their goals, and I do not believe anybody! (male, old, scholar, Dagestan, Makhachkala)

Until traditionalist views are overcome in one way or another - for example, by the ideology of religious reformation - and until this ideological space is cleared, liberal views will not take root.

On the other hand, Islamic countries also experience the "dark side" of modernity. In many of them, rigid authoritarian regimes supported from without have dominated for a prolonged period; these regimes do not recognize democratic procedures, violate human rights, and monopolize the economic benefits of modernization within the ruling group without attempting to mitigate the associated social costs. In these conditions, fundamentalist Islam serves as an ideology of protest, making it possible to mobilize those who are dissatisfied with the current situation. Liberal Islam cannot meet such a need or its response is much weaker than that of ideologies that are more radical. In many cases its representatives "are either cut off from their own society or, more often are themselves [. . .] part of traditional networks and combine rhetorical democracy with social patronage" (Roy 2004, 82); that is, they are implicated in patron-client relations.

Post-World War II theories of modernization have not taken into account the complex dialectic of social transformation examined above, because they are based precisely on the idea that modernization is a universal recipe for the transition from a traditional to a modern society, and that it would necessarily succeed if all of the ingredients were present and in the required proportions. However, such a "straight path" to modernization can only be an artificial construct, imposed on society from without and not derived from existing social conditions and demands. Hence its imposition will be unstable, inevitably involving violent coercion and therefore fraught with se- 
rious conflict and backward steps, as has been shown by the history of many states, including those with an Islamic population. At the same time, the collapse of the modernization paradigm as framed in such simplified terms has led to the fact that the modernizing agenda has become unfashionable in the social sciences. Some have proposed the ideological possibility of "multiple" or "alternative" modernities as opposed to one "universal prescription" (see, for example, Eisenstadt 2003 and Gaonkar 2001), but this idea has not been seriously developed either on the theoretical level or at the level of concrete research. As a result, in fact, the baby has been thrown out with the bathwater - the social sciences have lost the tools for analyzing those large-scale social changes that accompany the processes of globalization, the transition from rural to urban civilization and similar shifts taking place in modern conditions, regardless of whether we call them modernization or not. These tools need to be revalidated or it will be practically impossible to adequately understand and assess the complex and ambiguous processes of transformation that are taking place, including those in the Islamic world. Identifying the role of religion and ideology within their framework is one of the necessary tasks that we face. Perhaps, considering the modern processes in Islam according to the logic of reformation will allow us to advance in this direction.

\section{References}

An-Naim, Abdullahi Ahmed. 1999. Na puti k islamskoi reformatsii (grazhdanskie svobody, prava cheloveka i mezhdunarodnoe pravo) [Toward an Islamic reformation: Civil liberties, human rights and international law]. Moscow: Muzei i obshchestvennyi tsentr imeni Andreia Sakharova.

Armstrong, Karen. 2013. Bitva za Boga: Istoriia fundamentalizma [Battle for God: The history of fundamentalism]. Moscow: Al'pina non-fikshn.

Atran, Scott. 2016. Razgovarivaia s vragom: Religioznyi ekstremizm, sviashchennye tsennosti $i$ chto znachit byt' chelovekom [Talking to the enemy: Religious extremism, sacred values and what it means to be human]. Moscow: Kar'era press.

Chedvig, O. [Chadwick, Owen]. 2011. Reformatsiia: Protivostoianie katolikov i protestantov $v$ Zapadnoi Evrope XVI-XVII vv. [Reformation: The confrontation between Catholics and Protestants in Western Europe in the XVI-XVII centuries]. Moscow: ZAO Izdatel'stvo Tsentropoligraf.

Eisenstadt, Shmuel Noah. 2003. "Multiple Modernities.” In Comparative Civilizations and Multiple Modernities. Part 2. Leiden: Brill.

Furman, Dmitrii Efimovich. 2011. "Reforma islama po Mokhamedu Tahe i Ahmedu AnNaimu" [The reform of Islam by Mohamed Taha and Ahmed An-Naim]. In A. A. An-Naima, Na puti $k$ islamskoi reformats. In D. E. Furman, Izbrannoe, 20123. Moscow: Izdatel'skii dom "Territoriia budushchego." 
Furman, Dmitrii Efimovich. 2011a. “Ideologiia reformatsii i ee rol' v stanovlenii burzhuaznogo obshchestvennogo soznaniia" [The ideology of the reformation and its role in the formation of bourgeois public consciousness]. In Izbrannoe by D. E. Furman, 41-109. Moscow: Izdatel'skii dom "Territoriia budushchego."

Gaonkar, Dilip P. 2001. “On Alternative Modernities.” In Alternative Modernities, ed. D. P. Gaonkar, 1-23. Durham, NC: Duke University Press.

Gellner, Ernest. 2004. Usloviia svobody: Grazhdanskoe obshchestvo i ego istoricheskie soperniki [Conditions of liberty: Civil society and its historical rivals]. Moscow: Moskovskaia shkola politicheskikh issledovanii.

Gorski, Philip S. 2003. The Disciplinary Revolution: Calvinism and the Rise of the State in Early Modern Europe. Chicago: University of Chicago Press.

Ignatenko, Aleksandr. 2003. "Raskolotaia Umma v ozhidanii sudnogo dnia (Novyi vzgliad so starykh pozitsii)" [A divided Ummah in expectation of Judgment Day (a new view from old positions)]. Otechestvennye zapiski 5 .

Kazenin, Konstantin, and Irina Starodubrovskaya. 2014. "Severnyi Kavkaz: Quo vadis? Ekspertnyi doklad” [North Caucasus: Quo vadis? An expert report]. Polit.ru, accessed August 30, 2017, http://polit.ru/article/2014/01/14/caucasus/.

Kalkhun, K. [Calhoun, Craig J.]. 2006. Natsionalizm [Nationalism]. Moscow: Izdatel'skii dom "Territoriia budushchego."

Kisriev, Enver F. 2004. Islam i vlast'v Dagestane [Islam and power in Dagestan]. Moscow: OGI.

Liuis (Lewis), Bernard. 2003. Chto ne tak? Put' Zapada i Blizhnego Vostoka: Progress $i$ traditsionalizm [What went wrong? The path of the West and the Middle East: Progress and traditionalism]. Moscow: ZAO "Olimp-Biznes."

MacCulloch, Diarmaid. 2003. The Reformation: A History. New York: Penguin.

Makarov, D. V. 2000. Ofitsial'nyi i neofitsial'nyi Islam v Dagestane [Official and unofficial Islam in Dagestan]. Moscow.

Pain, E. A. 2002. "Sotsial'naia priroda ekstremizma i terrorizma" [The social nature of extremism and terrorism]. Obshchestvennye nauki i sovremennost' 4:113-24.

Phillips, Andrew. 2005. "The Protestant Ethic and the Spirit of Jihadism - Transnational Religious Insurgencies and the Transformation of International Orders." Review of International Studies 36 (2): 257-80.

Pipes, Daniel. 2008. In the Path of God: Islam and Political Power; Preface to the Transaction. New York: Basic Books, 1983.

Porozovskaia, B. D. 1995. "Martin Liuter: Ego zhizn' i reformatorskaia deiatel'nost”" [Martin Luther: His life and reforming activity.] In Jan Gus, Martin Liuter, Zhan Kal'vin, Torkvemada, Loiola: Biograficheskie ocherki. Moscow: Respublika.

Roy, Olivier. 2004. Globalized Islam: The Search for a New Ummah. New York: Columbia University Press.

Veber M. [Weber, Max]. 2011. Protestantskaia etika i dukh kapitalizma [The Protestant ethic and the spirit of capitalism]. Moscow: Direkt-media.

Walzer, Michael. 1965. The Revolution of the Saints: A Study in the Origins of Radical Politics. Cambridge, MA: Harvard University Press. 